\title{
ANALISIS RTRW KOTA PADANG TAHUN 2010-2030 UNTUK PUSAT \\ PENGEMBANGAN WILAYAH KOTA DI KAWASAN AIA PACAH KECAMATAN KOTO TANGAH
}

\author{
Anggun Oktavia ${ }^{1}$, Yurni Suasti ${ }^{2}$, Ahyuni $^{2}$ \\ Program StudiGeografi \\ FakultasIlmuSosial, UniversitasNegeri Padang \\ Email :anggunoktavia995@gmail.com
}

\begin{abstract}
ABSTRAK
Penelitian ini bertujuan menganalisis kesesuaian lokasi kawasan Aia Pacah Kecamatan Koto Tangah sebagai sub pusat pelayanan kota di Kota Padang dan mendeskripsikan kesesuaian RTRW Kota Padang tahun 2010-2030 dengan ketersediaan fasilitas pusat pengembangan wilayah kota di Kawasan Aia Pacah Kecamatan Koto Tangah.Penelitian ini merupakan analisis data sekunder meliputi jumlah penduduk kelurahan di Kecamatan Koto Tangah, jumlah penduduk kecamatan di Kota Padang, jarak antar kelurahan di Kecamatan Koto Tangah, jarak antar Kecamatan di Kota Padang, dan jumlah fasilitas umum pada tahun 2017. Teknik penelitian ini menggunakan analisis potensial demografis dan analisis hirarki. Hasil penelitian ini menunjukkan kelurahan Aia Pacah kurang sesuai dijadikan sebagai pusat pengembangan wilayah kota, karena interaksi antar kelurahan tergolong rendah. Sedangkan Kelurahan Lubuk Buaya sesuai dijadikan sebagai pusat pengembangan wilayah kota karena kelurahan tersebut dari segi fasilitas dan interaksi tergolong tinggi. Untuk kesesuaian lokasi pengembangan wilayah kota pada Kecamatan di Kota Padang adalah Kecamatan Koto Tangah dan Kecamatan Padang Timur, karena dari segi fasilitas dan interaksi pada kedua kecamatan tersebut sangat mendukung dan memadai dijadikan sebagai pusat pengembangan wilayah kota di Kota Padang.
\end{abstract}

Kata Kunci : Pengembangan Wilayah, RTRW, Potensial Demografis, Hirarki

\section{ABSTRACT}

This study aims to analyze the suitability of the location of the Aia Pacah area of Koto Tangah District as a sub-service center of the City in Padang City and describes the suitability of the Padang City Spatial Plan 2010-2030 with the availability of urban development center facilities in Aia Pacah District, Koto Tangah District. This research is a secondary data analysis which includes the population of villages in Koto Tangah Subdistrict, the population of sub-districts in Padang City, the distance between villages in Koto Tangah Subdistrict, the distance between Subdistricts in Padang City, and the number of community facilities in 2017. Data collection techniques are analysis of demographic potential and hierarchical analysis. The results of this study indicate that the village of Aia Pacah is not suitable to be the center of urban development, because the interaction between the whole is relatively low. Whereas Lubuk Buaya village is suitable to be used as a center for urban area development because the kelurahan in terms of facilities and interaction is relatively high. For the suitability of the location of urban development in the sub-districts of Padang City, it is Koto Tangah Subdistrict and Padang Timur Subdistrict, because in terms of facilities and interactions in the two sub-districts it is very supportive and sufficient to be used as an urban development center in Padang City.

Keywords: Type of Business, Labor Absorption And Reven

\footnotetext{
${ }^{1}$ Mahasiswa Program StudiGeografiUntukWisuda September 2018

${ }^{2}$ DosenJurusanGeografiFakultas IlmuSosialUniversitasNegeri Padang Dra. YurniSuasti,M.Si. Ahyuni, S.T, M.Si
} 


\section{PENDAHULUAN}

Pembangunan merupakan upaya yang dilakukan secara terencana dalam melakukan perubahan dengan tujuan utama untuk memperbaiki dan meningkatkan taraf hidup masyarakat, meningkatkan kesejahteraan serta meningkatkan kualitas hidup.

Kota Padang dalam pelaksanaan pembangunannya juga tidak lepas dari upaya untuk mewujudkan visi sebagai komitmen bersama dalam jangka panjang. Salah satu dari visi Kota Padang pada jangka panjang tahun 2020 yaitu "Terwujudnya masyarakat madani yang berbasis industri, perdagangan, dan jasa yang unggul dan berdaya saing tinggi dalam kehidupan perkotaan yang tertib dan teratur".

Dalam rangka mewujudkan visi tersebut, Kota Padang telah melakukan perencanaan pengembangan wilayah sebagaimana tercantum dalam rencana tata ruang wilayah (RTRW) Kota Padang 2010-2020, dilakukan dengan menerapkan strategi sebagai berikut (1)Menetapkan kawasan yang dibatasi pengembangannya: kawasan lindung, kawasan pemugaran (cagar budaya), kawasan yang memiliki kerawanan terhadap bencana (karena kondisi morfologi lahan/kelerengan lahan), serta kawasan yang rawan terhadap ancaman bencana (karena letak geografis lahan) seperti pada kawasan tepi sungai, tepi laut. (2) Menetapkan kawasan yang di dorong pengembangannya: ruang-ruang kota yang sudah berkembang baik, dan diprediksi terjadi peningkatan pemanfaatan intensitas ruang akibat pengembangan kegiatan kota.
Menetapkan kawasan yang dikendalikan pengembangnnya: ruang kota yang belum berkembang tetapi memiliki potensi sebagai kawasan baru untuk kegiatan permukiman, perdagangan dan jasa atau untuk kegiatan industri, khususnya industri yang berbasis perikanan atau maritim. (BAPPEDA, 2010).

Memperkuat rencana tata ruang wilayah (RTRW) tersebut dikeluarkan PP No 26 tahun 2011, dalam PP tersebut diantaranya dinyatakan bahwa untuk mengatasi persoalan konsentrasi masyarakat di kawasan pantai Kota Padang yang rawan bahaya gempa bumi dan tsunami. Selain itu, untuk mendekatkan pelayanan kepada masyarakat, mempercepat pertumbuhan ekonomi dan pembangunan dalam rangka mewujudkan kesejahteraan masyarakat di Kota Padang. Maka, pemerintah Kota Padang telah memindahkan pusat pemerintahan Kota Padang dari Kecamatan Padang Barat ke kawasan Aia Pacah Kecamatan Koto Tangah.

Dalam rencana tata ruang wilayah (RTRW) Kota Padang tersebut menyatakan bahwa pada periode 20102030, kawasan Aia Pacah Kecamatan Koto Tangah ditetapkan sebagai kawasan strategis dan sekaligus ditetapkan sebagai pusat pelayanan kota. (BAPPEDA, 2012).

Menurut Tarigan (2005), secara geografis daerah-daerah atau lokasi yang perlu diperuntukan sebagai pusat pelayanan adalah daerah yang memiliki fasilitas dan kemudahan sehingga menjadi pusat daya tarik untuk pusat 
pengembangan wilayah (pole of attraction), yang menyebabkan berbagai macam usaha tertarik untuk berlokasi disitu, termasuk penduduk juga tertarik untuk datang ke tempat yang bersangkutan dan memanfaatkan fasilitas yang ada.

Di Kota Padang sebagaimana disebutkan di atas, sub pelayanan kota di pusatkan di Kelurahan Aia Pacah Kecamatan Koto Tangah yang diharapkan dapat menjadi pemicu pertumbuhan kawasan di sekitarnya, dan 10 Kecamatan lainnya terdapat di Kota Padang yakni Kecamatan Kuranji, Kecamatan Pauh, Kecamatan Nanggalo, Kecamatan Padang Barat, Kecamatan Padang Timur, Kecamatan Padang Selatan, Kecamatan Padang Utara, Kecamatan Lubuk Kilangan, Kecamatan Lubuk Begalung, Kecamatan Bungus Teluk Kabung.

Menurut W. Christaller dan Losch, untuk menganalisis suatu wilayah yang dapat difungsikan sebagai pusat pelayanan, termasuk sub pelayanan kota, dapat menganalisis potensial demografis dan ketersediaan fasilitas di daerah yang bersangkutan. (Dedi, 2011). Potensial demografis dihitung dangan cara membagi jarak masing-masing sub wilayah di dalam daerah yang bersangkutan dengan jumlah penduduk total daerah tersebut. Misalnya satu wilayah kecamatan A dengan jumlah penduduk 186091 jiwa, terdapat 13 kelurahan yakni (A,B,C,D,E) dan jarak A ke B adalah 16 $\mathrm{km}$, maka potensial demografisnya sebesar 10,94.

Penelitian ini untuk menganalisis kesesuaian lokasi hasil Kelurahan Aia
Pacah Kecamatan Koto Tangah sebagai sub pelayanan Kota. Untuk dapat melakukan perencanaan yang tepat dan untuk mengantisipasi kendala yang mungkin timbul, perlu mengetahui potensi daerah bersangkutan, maka perlu dilakukan analisis rencana tata ruang Kota Padang Tahun 2010-2030 untuk pusat pengembangan wilayah Kota di kawasan Aia Pacah Kecamatan Koto Tangah.

\section{Metodologi Penelitian}

Penelitian ini merupakan analisis data sekunder, tentang kesesuaian lokasi kelurahan Aia Pacah sebagai sub pusat pelayanan kota di Kota Padang dan kesesuaian RTRW Kota Padang tahun 2010-2030 dengan ketersediaan fasilitas pusat pengembangan wilayah kota di Kawasan Aia Pacah Kecamatan Koto Tangah. untuk analisis tersebut digunakan teknik analisis potensial demografis dan analisis hirarki, sebagaimana terdapat pada tabel. 1 . 


\section{TeknisAnalisis Data}

Tabel. 1 Teknik Analisis Data

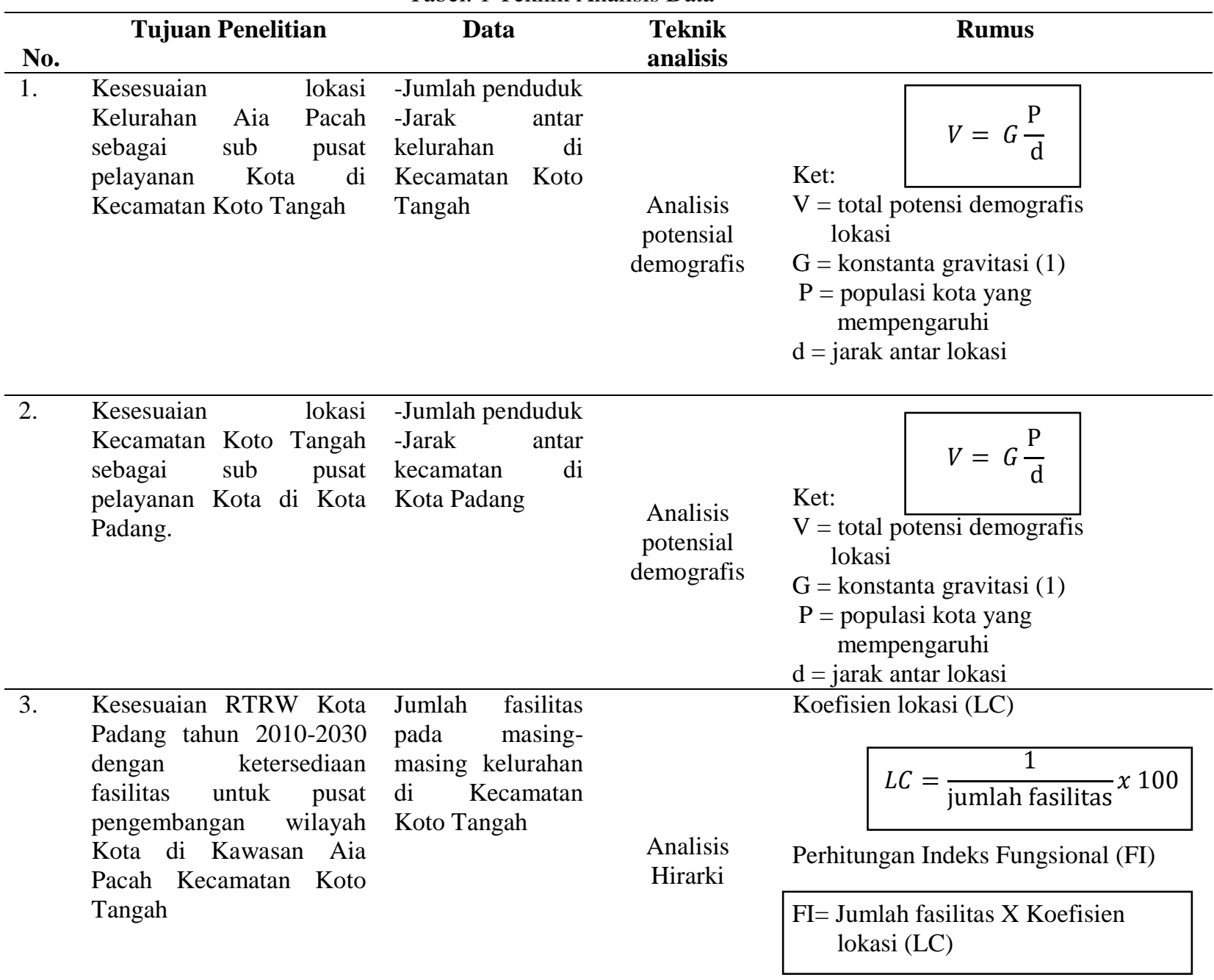

4. Kesesuaian RTRW Kota Jumlah fasilitas Padang tahun 2010-2030 pada masingdengan ketersediaan masing kecamatan fasilitas untuk pusat di Kota Padang pengembangan wilayah kota di kecamatan Koto Tangah di Kota Padang.

\section{Koefisien lokasi (LC)}

$$
L C=\frac{1}{\text { jumlah fasilitas }} \times 100
$$

Analisis

Hirarki Perhitungan Indeks Fungsional (FI)

FI= Jumlah fasilitas X Koefisien lokasi (LC)

Sumber: Dedi NS Setiono, 2011 


\section{HASIL DAN PEMBAHASAN}

1. Kesesuaian lokasi kawasan Aia Pacah sebagai sub pusat pelayanan kota di Kecamatan Koto tangah

a) Kesesuaian lokasi Kelurahan sebagai sub pusat pelayanan kota di Kecamatan Koto Tangah

Sebagaimana disebutkan pada bagian metodologi yang menggunakan teknik analisis potensial demografis dan teknik analisis hirarki. Untuk melihat jarak antar kelurahan terdapat pada tabel. 2.

Berdasarkan data tabel. 2, Kecamatan Koto Tangah terdapat 13kelurahan, setelah menghitung jumlah penduduk kelurahan dan jarak antar kelurahan, maka dapat melakukan perhitungan potensial demografis di masing-masing lokasi, yang merupakan penjumlahan total dari seluruh pengaruh lokasi pusat pengembangan termasuk dirinya sendiri dilihat dari jumlah penduduk dengan jarak antar kelurahan di Kecamatan Koto Tangah. Untuk melihat Hasil perhitungan potensial demografis masing-masing kelurahan di Kecamatan Koto Tangah terdapat pada tabel. 3 .

Tabel. 2 Jumlah Penduduk dan Jarak Antar Kelurahan Di Kecamatan Koto Tangah

\begin{tabular}{|c|c|c|c|c|c|c|c|c|c|c|c|c|c|c|}
\hline No & $\mathrm{KM}$ & $\begin{array}{c}\text { Aia } \\
\text { pacah }\end{array}$ & $\begin{array}{c}\text { Dadok } \\
\text { tunggul } \\
\text { itam }\end{array}$ & $\begin{array}{l}\text { Lubuk } \\
\text { minturun }\end{array}$ & $\begin{array}{c}\text { Balai } \\
\text { gadang }\end{array}$ & $\begin{array}{l}\text { Bungo } \\
\text { pasang }\end{array}$ & $\begin{array}{l}\text { Batang } \\
\text { kabung }\end{array}$ & $\begin{array}{l}\text { Lubuk } \\
\text { buaya }\end{array}$ & $\begin{array}{l}\text { Padang } \\
\text { sarai }\end{array}$ & $\begin{array}{c}\text { Koto } \\
\text { panjang } \\
\text { ikua koto }\end{array}$ & $\begin{array}{l}\text { Koto } \\
\text { pulai }\end{array}$ & $\begin{array}{l}\text { Batipuh } \\
\text { panjang }\end{array}$ & $\begin{array}{l}\text { Parupuk } \\
\text { tabing }\end{array}$ & $\begin{array}{c}\text { Pasir } \\
\text { nan } \\
\text { tigo }\end{array}$ \\
\hline 1 & Aia pacah & 0 & 10 & 11 & 6 & 8 & 14 & 13 & 16 & 7 & 13 & 11 & 11 & 13 \\
\hline 2 & Dadok tunggul itam & 10 & 0 & 14 & 13 & 4 & 10 & 13 & 17 & 6 & 9 & 14 & 7 & 12 \\
\hline 3 & Lubuk minturun & 11 & 14 & 0 & 11 & 12 & 18 & 16 & 17 & 9 & 12 & 15 & 15 & 20 \\
\hline 4 & Balai gadang & 6 & 13 & 11 & 0 & 8 & 6 & 8 & 10 & 5 & 3 & 6 & 11 & 8 \\
\hline 5 & Bungo pasang & 8 & 4 & 12 & 8 & 0 & 8 & 11 & 13 & 5 & 5 & 11 & 3 & 9 \\
\hline 6 & Batang kabung & 14 & 10 & 18 & 6 & 8 & 0 & 5 & 7 & 10 & 1 & 5 & 5 & 2 \\
\hline 7 & Lubuk buaya & 13 & 13 & 16 & 6 & 11 & 5 & 0 & 3 & 10 & 6 & 3 & 9 & 1 \\
\hline 8 & Padang sarai & 16 & 17 & 17 & 10 & 13 & 7 & 3 & 0 & 13 & 9 & 6 & 13 & 5 \\
\hline 9 & Koto panjang ikua koto & 7 & 6 & 9 & 5 & 5 & 10 & 10 & 13 & 0 & 6 & 8 & 7 & 10 \\
\hline 10 & Koto pulai & 13 & 9 & 12 & 3 & 5 & 1 & 6 & 9 & 6 & 0 & 6 & 5 & 3 \\
\hline 11 & Batipuh panjang & 11 & 14 & 15 & 6 & 11 & 5 & 3 & 6 & 8 & 6 & 0 & 10 & 4 \\
\hline 12 & Parupuk tabing & 11 & 7 & 15 & 11 & 3 & 5 & 9 & 13 & 7 & 5 & 10 & 0 & 8 \\
\hline 13 & Pasir nan tigo & 13 & 12 & 20 & 8 & 9 & 2 & 1 & 5 & 10 & 3 & 4 & 8 & 0 \\
\hline & Jumlah penduduk & 10.693 & 19.484 & 9.132 & 16.481 & 12.569 & 13.666 & 23.539 & 20.634 & 12.716 & 2.455 & 14.929 & 20.352 & 9.441 \\
\hline
\end{tabular}

Sumber: data sekunder, 2018 
Tabel. 3 Potensial Demografik masing-masing kelurahan di Kecamatan Koto Tangah

\begin{tabular}{|c|c|c|c|c|c|c|c|c|c|c|c|c|c|c|c|}
\hline No & KM & $\begin{array}{c}\text { Aia } \\
\text { pacah }\end{array}$ & $\begin{array}{c}\text { Dadok } \\
\text { tunggul } \\
\text { itam }\end{array}$ & $\begin{array}{c}\text { Lubuk } \\
\text { mintur } \\
\text { un }\end{array}$ & $\begin{array}{c}\text { Balai } \\
\text { gadang }\end{array}$ & $\begin{array}{l}\text { Bungo } \\
\text { pasang }\end{array}$ & $\begin{array}{l}\text { Batang } \\
\text { kabung }\end{array}$ & $\begin{array}{l}\text { Lubuk } \\
\text { buaya }\end{array}$ & $\begin{array}{c}\text { Padang } \\
\text { sarai }\end{array}$ & $\begin{array}{c}\text { Koto } \\
\text { panjan } \\
\text { g ikua } \\
\text { koto }\end{array}$ & $\begin{array}{l}\text { Koto } \\
\text { pulai }\end{array}$ & $\begin{array}{c}\text { Batipu } \\
\text { h } \\
\text { panjan } \\
\text { g }\end{array}$ & $\begin{array}{c}\text { Parupu } \\
\text { k } \\
\text { tabing }\end{array}$ & $\begin{array}{l}\text { Pasir } \\
\text { nan } \\
\text { tigo }\end{array}$ & Total \\
\hline 1 & Aia pacah & 1069 & 972 & 891 & 1527 & 1188 & 712 & 763 & 629 & 1336 & 763 & 891 & 891 & 763 & 12395 \\
\hline 2 & $\begin{array}{c}\text { Dadok } \\
\text { tunggul } \\
\text { itam }\end{array}$ & 972 & 1948 & 1298 & 1391 & 3896 & 1771 & 1391 & 1082 & 2783 & 1948 & 1298 & 2435 & 1498 & 23711 \\
\hline 3 & $\begin{array}{c}\text { Lubuk } \\
\text { minturun }\end{array}$ & 891 & 1298 & 9132 & 761 & 702 & 480 & 537 & 507 & 913 & 702 & 507 & 507 & 434 & 17371 \\
\hline 4 & $\begin{array}{c}\text { Balai } \\
\text { gadang }\end{array}$ & 1527 & 1391 & 761 & 1648 & 1831 & 2354 & 2354 & 1498 & 2746 & 4120 & 2354 & 1373 & 1831 & 25788 \\
\hline 5 & $\begin{array}{l}\text { Bungo } \\
\text { pasang }\end{array}$ & 1188 & 3896 & 702 & 1831 & 1256 & 1396 & 1047 & 897 & 2094 & 2094 & 1047 & 3142 & 1256 & 21846 \\
\hline 6 & $\begin{array}{l}\text { Batang } \\
\text { kabung }\end{array}$ & 712 & 1771 & 480 & 2354 & 1396 & 1366 & 2277 & 1708 & 1242 & 6833 & 2277 & 2277 & 4555 & 29248 \\
\hline 7 & $\begin{array}{l}\text { Lubuk } \\
\text { buaya }\end{array}$ & 763 & 1391 & 537 & 2354 & 1047 & 2277 & 2353 & 5884 & 2139 & 3362 & 5884 & 2353 & 11769 & 42113 \\
\hline 8 & $\begin{array}{c}\text { Padang } \\
\text { sarai }\end{array}$ & 629 & 1082 & 507 & 1498 & 897 & 1708 & 5884 & 2063 & 1473 & 2063 & 2947 & 1473 & 3439 & 25663 \\
\hline 9 & $\begin{array}{c}\text { Koto } \\
\text { panjang } \\
\text { ikua koto } \\
\end{array}$ & 1336 & 2783 & 913 & 2746 & 2094 & 1242 & 2139 & 1473 & 1271 & 1816 & 1412 & 1589 & 1156 & 21970 \\
\hline 10 & Koto pulai & 763 & 1948 & 702 & 4120 & 2094 & 6833 & 3362 & 2063 & 1816 & 2455 & 350 & 409 & 613 & 27528 \\
\hline 11 & $\begin{array}{l}\text { Batipuh } \\
\text { panjang }\end{array}$ & 891 & 1298 & 507 & 2354 & 1047 & 2277 & 5884 & 2947 & 1412 & 350 & 1492 & 1357 & 2985 & 24801 \\
\hline 12 & $\begin{array}{c}\text { Parupuk } \\
\text { tabing }\end{array}$ & 891 & 2435 & 507 & 1373 & 3142 & 2277 & 2353 & 1473 & 1589 & 409 & 1357 & 2035 & 2261 & 22102 \\
\hline 13 & $\begin{array}{c}\text { Pasir nan } \\
\text { tigo }\end{array}$ & 763 & 1498 & 434 & 1831 & 1256 & 4555 & 11769 & 3439 & 1156 & 613 & 2985 & 2261 & 9441 & 42001 \\
\hline \multicolumn{2}{|c|}{ Jumlah penduduk } & 10.693 & 19.484 & 9.132 & 16.481 & 12.569 & 13.666 & 23.539 & 20.634 & 12.716 & 2.455 & 14.929 & 20.352 & 9.441 & \\
\hline
\end{tabular}

Tabel. 4 Hasil Perhitungan Potensial Demografis Jarak antar Kelurahan Kecamatan Koto Tangah

\begin{tabular}{llrr}
\hline No & \multicolumn{1}{c}{ Kelurahan } & $\begin{array}{r}\text { Jumlah Penduduk } \\
\text { (jiwa) }\end{array}$ & $\begin{array}{c}\text { Potensial } \\
\text { Demografis }\end{array}$ \\
\hline 1. & Lubuk Buaya & 23.539 & $\mathbf{4 2 1 1 3}$ \\
\hline 2. & Pasir Nan Tigo & 9.441 & 42001 \\
\hline 3. & Batang Kabung Ganting & 13.666 & 29248 \\
\hline 4. & Koto Pulai & 2.455 & 27528 \\
\hline 5. & Balai Gadang & 16.481 & 25788 \\
\hline 6. & Padang Sarai & 20.634 & 25663 \\
\hline 7. & Batipuh Panjang & 14.929 & 24801 \\
\hline 8. & Dadok Tunggul hitam & 19.484 & 23711 \\
\hline 9. & Bungo Pasang & 12.569 & 21846 \\
\hline 10. & Koto Panjang Ikua Koto & 12.716 & 21970 \\
\hline 11. & Parupuk Tabing & 20.352 & 22102 \\
\hline 12. & Lubuk Minturun & 9.132 & 17371 \\
13. & Air Pacah & 10.693 & 12395 \\
\hline
\end{tabular}

Sumber: hasil analisis sekunder, 2018

Berdasarkan hasil analisis yang ditampilkan pada tabel.3 memperlihatkan bahwa Kelurahan Aia Pacah memiliki daya tarik sebesar 12.395, dan paling kecil dibandingkan dengan 12 kelurahan lainnya. Mengacu pada tabel tersebut yang paling sesuai dijadikan sebagai pusat pengembangan wilayah kota adalah Kelurahan Lubuk Buaya dengan daya tarik sebesar 42.113 
karena konsentrasi jumlah penduduk terbanyak terdapat di Kelurahan b). Kesesuaian lokasi Kecamatan sebagai sub pusat pelayanan kota di Kota Padang

Sebagaimana disebutkan pada bagian metodologi yang menggunakan tersebut.

teknik analisis potensial demografis dan teknik analisis hirarki. Untuk menghitung jarak antar Kecamatan di Kota Padang terdapat pada tabel. 5.

Tabel. 5 Jumlah Penduduk dan Jarak Antar Kecamatan Di Kota Padang

\begin{tabular}{|c|c|c|c|c|c|c|c|c|c|c|c|c|c|}
\hline No & $\mathbf{K M}$ & A & B & $\mathrm{C}$ & $\mathrm{D}$ & $\mathrm{E}$ & $\mathrm{F}$ & G & $\mathrm{H}$ & I & $\mathrm{J}$ & $\mathrm{K}$ & $\begin{array}{c}\text { Jarak } \\
\text { Rata- } \\
\text { Rata }\end{array}$ \\
\hline 1 & $\mathrm{~A}$ & 0 & 16 & 24 & 8 & 12 & 16 & 19 & 10 & 24 & 23 & 45 & 17,9 \\
\hline 2 & B & 16 & 0 & 12 & 7 & 13 & 14 & 15 & 13 & 18 & 14 & 41 & 14,81 \\
\hline 3 & $\mathrm{C}$ & 24 & 12 & 0 & 13 & 21 & 22 & 24 & 19 & 13 & 16 & 45 & 19 \\
\hline 4 & $\mathrm{D}$ & 8 & 7 & 13 & 0 & 10 & 9 & 19 & 7 & 18 & 16 & 38 & 13,18 \\
\hline 5 & $\mathrm{E}$ & 12 & 13 & 21 & 10 & 0 & 3 & 11 & 5 & 20 & 10 & 31 & 12,36 \\
\hline 6 & $\mathrm{~F}$ & 16 & 14 & 22 & 9 & 3 & 0 & 6 & 6 & 19 & 6 & 30 & 11,9 \\
\hline 7 & G & 19 & 15 & 24 & 19 & 11 & 6 & 0 & 12 & 18 & 8 & 26 & 14,36 \\
\hline 8 & $\mathrm{H}$ & 10 & 13 & 19 & 7 & 5 & 6 & 12 & 0 & 21 & 11 & 37 & 12,81 \\
\hline 9 & I & 24 & 18 & 13 & 18 & 20 & 19 & 18 & 21 & 0 & 14 & 24 & 17,18 \\
\hline 10 & $\mathrm{~J}$ & 23 & 14 & 16 & 16 & 10 & 6 & 8 & 11 & 14 & 0 & 26 & 13,09 \\
\hline 11 & K & 45 & 41 & 45 & 38 & 31 & 30 & 26 & 37 & 24 & 26 & 0 & 31,18 \\
\hline \multicolumn{2}{|c|}{ Jumlah } & 197 & 163 & 209 & 145 & 136 & 131 & 158 & 141 & 189 & 144 & 343 & \\
\hline \multicolumn{2}{|c|}{$\begin{array}{c}\text { Jumlah } \\
\text { penduduk }\end{array}$} & 186091 & 144063 & 70225 & 60643 & 45961 & 79315 & 59523 & 70624 & 54529 & 119322 & 24672 & \\
\hline
\end{tabular}

Berdasarkan data tabel. 5, Kota Padang terdapat 11 kecamatan, setelah menghitung jumlah penduduk kecamatan dan jarak antar kecamatan, maka dapat melakukan peerhitungan potensial demografis di masing-masing lokasi, yang merupakan penjumlahan total dari seluruh pengaruh lokasi pusat pengembangan termasuk dirinya sendiri

Tabel. 6Potensial Demografik Hipotesis Kecamatan Di Kota Padang

\begin{tabular}{|c|c|c|c|c|c|c|c|c|c|c|c|c|c|}
\hline No & $\mathbf{K M}$ & $\mathbf{A}$ & B & $\mathbf{C}$ & D & $\mathbf{E}$ & $\mathbf{F}$ & $\mathbf{G}$ & $\mathbf{H}$ & I & $\mathbf{J}$ & $K$ & Total \\
\hline 1 & A & 18,60 & 10,94 & 7,44 & 20,67 & 14,31 & 10,94 & 9,30 & 16,91 & 7,44 & 7,75 & 4,04 & 128,87 \\
\hline 2 & $\mathrm{~B}$ & 10,94 & 14,40 & 11,08 & 18,00 & 10,29 & 9,60 & 9,00 & 10,29 & 7,58 & 9,60 & 3,43 & 114,21 \\
\hline 3 & $\mathrm{C}$ & 7,44 & 11,08 & 70,22 & 5,01 & 3,19 & 3,05 & 2,80 & 3,51 & 5,01 & 4,13 & 1,52 & 116,96 \\
\hline 4 & $\mathrm{D}$ & 20,67 & 18,00 & 5,01 & 60,64 & 5,51 & 6,06 & 3,03 & 7,58 & 3,19 & 3,56 & 1,55 & 134,8 \\
\hline 5 & $\mathrm{E}$ & 14,31 & 10,29 & 3,19 & 5,51 & 45,96 & 11,4 & 3,83 & 7,66 & 2,18 & 4,17 & 1,43 & 109,93 \\
\hline 6 & $\mathrm{~F}$ & 10,94 & 9,60 & 3,05 & 6,06 & 11,49 & 79,31 & 11,33 & 11,33 & 3,96 & 11,33 & 2,55 & 160,95 \\
\hline 7 & $\mathrm{G}$ & 9,30 & 9,00 & 2,80 & 3,03 & 3,83 & 11,33 & 59,52 & 4,57 & 3,13 & 6,61 & 2,20 & 115,32 \\
\hline 8 & $\mathrm{H}$ & 16,91 & 10,29 & 3,51 & 7,58 & 7,66 & 11,33 & 4,57 & 70,62 & 3,21 & 5,88 & 1,85 & 143,05 \\
\hline 9 & I & 7,44 & 7,58 & 5,01 & 3,19 & 2,18 & 3,96 & 3,13 & 3,21 & 54,52 & 3,63 & 2,18 & 96,03 \\
\hline 10 & $\mathrm{~J}$ & 7,75 & 9,60 & 4,13 & 3,56 & 4,17 & 11,33 & 6,61 & 5,88 & 3,63 & 11,93 & 4.41 & 73 \\
\hline 11 & $\mathrm{~K}$ & 4,04 & 3,43 & 1,52 & 1,55 & 1,43 & 2,55 & 2,20 & 1,85 & 2,18 & 4,41 & 24,67 & 49,83 \\
\hline \multicolumn{2}{|c|}{$\begin{array}{c}\text { Jumlah } \\
\text { penduduk }\end{array}$} & 186091 & 144063 & 70225 & 60643 & 45961 & 79315 & 59523 & 70624 & 54529 & 119322 & 24672 & \\
\hline
\end{tabular}

Keterangan: A. Kec Koto tangah, B. Kec. Kuranji, C. Kec. Pauh, D Kec, Nanggalo, E. Kec. Padang Barat, F. Kec. Padang Timur, G. Kec. Padang Selatan, H. Kec. Padang utara, I. Kec. Lubuk Kilangan, J. Kec. Lubuk begalung, K. Kec. Bungus Teluk kabung

Sumber: hasil analisis sekunder, 2018 dilihat dari jumlah penduduk kecamatan dengan jarak antar kecamatan di Kota Padang. Hasil perhitungan potensial demografis masing-masing kecamatan di Kota Padang terdapat pada tabel. 6 . 
Tabel. 7 Hasil Perhitungan Potensial Demografis Jarak antar Kecamatan di Kota Padang

\begin{tabular}{|c|c|c|c|}
\hline \multirow[b]{2}{*}{ No } & \multirow[b]{2}{*}{ Kecamatan } & \multicolumn{2}{|c|}{ Analisis Potensial Demografis } \\
\hline & & $\begin{array}{l}\text { Jumlah Penduduk } \\
\text { (Jiwa) }\end{array}$ & $\begin{array}{c}\text { potensial } \\
\text { demografis }\end{array}$ \\
\hline 1. & Padang Timur & 79.315 & 160,95 \\
\hline 2. & Padang Utara & 70.624 & 143,05 \\
\hline 3. & Nanggalo & 60.643 & 134,8 \\
\hline 4. & Koto Tangah & 186.091 & 128,87 \\
\hline 5. & Pauh & 70.225 & 116,96 \\
\hline 6. & Padang Selatan & 59.523 & 115,32 \\
\hline 7. & Kuranji & 144.063 & 114,21 \\
\hline 8. & Padang Barat & 45.961 & 109,93 \\
\hline 9. & Lubuk Kilangan & 54.529 & 96,03 \\
\hline 10. & Lubuk Begalung & 119.322 & 73 \\
\hline 11. & Bungus Teluk Kabung & 24.672 & 49,83 \\
\hline
\end{tabular}

Sumber: hasil analisis, 2018

Berdasarkan data tabel. 6 Koto Tangah dengan cara mengalikan memperlihatkan bahwa Kecamatan jumlah masing-masing fasilitas dengan Koto Tangah memiliki daya tarik nilai koefosien lokasi yang terdapat sebesar 128.87, dan jika dibandingkan dengan 10 kelurahan lainnya mengacu pada tebel tersebut yang paling sesuai dijadikan sebagai pusat pengembangan wilayah kota adalah Kecamatan Padang Timur sebesar 160,95 karena dilihat dari pengaruh lokasi pusat pengembangan termasuk dirinya sendiri mengacu pada kecamatan tersebut.

2. Kesesuaian RTRW Kota Padang Tahun 2010-2030 Dengan Ketersediaan Fasilitas Untuk Pusat Pengembangan Wilayah Kota Di Kawasan Aia Pacah Kecamatan Koto Tangah

a). Kesesuaian RTRWdengan

ketersediaan fasilitas di Kecamatan Koto Tangah

Untuk menentukan tingkat kepentingan fasilitas di suatu wilayah, sebagaimana pada bagian metodologi dengan menggunakan analisis hirarki, dengan melihat jumlah fasilitas pada masing-masing kelurahan di Kecamatan pada tabel. 8

Tabel. 8 Hirarki Pusat Kegiatan Di Kecamatan Koto Tangah

\begin{tabular}{llrr}
\hline No & \multicolumn{1}{c}{$\begin{array}{c}\text { Nama } \\
\text { Kelurahan }\end{array}$} & $\begin{array}{c}\text { Indeks } \\
\text { Fungsional }\end{array}$ & Orde \\
\hline 1 & Lubuk buaya & 244.944 & I \\
\hline 2 & Parupuk tabing & 209.503 & II \\
\hline 3 & Aia pacah & 204.706 & III \\
\hline 4 & Balai gadang & 188.883 & IV \\
\hline 5 & lubuk minturun & 169.616 & V \\
\hline 6 & Padang sarai & 138.793 & VI \\
\hline 7 & Dadok tunggul & 133.214 & VII \\
\hline 8 & itam & 125.017 & VIII \\
\hline 9 & Batang kabung & 120.082 & IX \\
\hline & Koto panjang & 84.172 & X \\
\hline 10 & ikua koto & 77.162 & XI \\
\hline 11 & pasir nan tigo & 13.731 & XII \\
\hline 12 & Koto pulai & 89.82 & XIII \\
\hline & Batipuh & panjang &
\end{tabular}

Sumber: hasil analisis sekunder, 2018

Berdasarkan pada tabel. 8 yang merupakan hasil analisis hirarki, yang berfungsi dikembangkan menjadi pusat pertumbuhan wilayah kota pada Kecamatan Koto Tangah, terdapat pada Kelurahan Lubuk Buaya yang memiliki hirarki yang paling tinggi sebesar 244.944. apabiladibandingkan dengan 
12 kelurahan lainnya maka Kelurahan Aia Pacah yang memiliki hirarki sebesar 204.706 dari segi fasilitas kelurahan Aia Pacah berpotensi untuk dikembangkan menjadi pusat pertumbuhan wilayah pada kelurahan tersebut.

b) Kesesuaian RTRWdengan ketersediaan fasilitas di Kota Padang

Untuk menentukan tingkat kepentingan fasilitas di suatu wilayah. Sebagaimana pada bagian metodologi dengan menggunakan analisis hirarki, data yang dibutuhkan adalh jumlah fasilitas pada masing-masing kelurahan di Kecamatan Koto Tangah dengan cara mengalikan jumlah masing-masing fasilitas dengan nilai koefisien lokasi disajikan pada tabel. 9

Tabel. 9 Hirarki Pusat Kegiatan Kecamatan Di Kota Padang

\begin{tabular}{llrr}
\hline No & $\begin{array}{c}\text { Nama } \\
\text { Kecamatan }\end{array}$ & $\begin{array}{r}\text { Indeks } \\
\text { fungsional }\end{array}$ & Orde \\
1 & Koto tangah & 374,325 & I \\
\hline 2 & Padang timur & 234,355 & II \\
\hline 3 & Kuranji & 204,071 & III \\
\hline 4 & Padang barat & 200,411 & IV \\
\hline \multirow{2}{*}{5} & Lubuk & & \\
\hline 6 & begalung & 184,489 & V \\
\hline 7 & Padang utara & 173,268 & VI \\
\hline 8 & Pauh & 151,935 & VII \\
\cline { 2 - 4 } & Bungus telutan & 138,933 & VIII \\
\hline 9 & kabung & 119,595 & IX \\
\cline { 2 - 4 } & Lubuk & & \\
10 & kilangan & 101,493 & X \\
\cline { 2 - 4 } 11 & Nanggalo & 98,984 & XI \\
\hline
\end{tabular}

Sumber: hasil perhitungan, 2018

Berdasarkan pada tabel. 9 kecamatan yang berpotensi untuk dikembangkan menjadi pusat pertumbuhan wilayah di Kota Padang berdasarkan hasil analisis hirarki terdapat pada Kecamatan Koto Tangah yang memiliki hirarki yang paling tinggi sebesar 374,325.apabila dibandingkan dengan 10 kelurahan lainnya kecamatan Koto Tangah yang sesuai untuk dijadikan sebagai pusat pengembangan wilayah kota pada kecamatan tersebut.

Perbandingan Pusat Pengembangan Wilayah Kota Antara Hasil Analisis DanKebijakan Dalam Rencana Tata Ruang Wilayah (RTRW)

\section{Kebijakan RTRW Kota Padang}

Terkait strategi pengembangan struktur ruang wilayah Kota Padang, pengembangan wilayah kota dalam perencanaan RTRW Kota Padang pada tahun 2010-2030 sebagai berikut:

a. Kawasan pusat kota mencakup wilayah Kecamatan Padang Barat, Kecamatan Padang Timur, Kecamatan Padang Utara, dan Kecamatan Padang Selatan yaitu Kawasan Pusat Kota.

b. Sub pusat pelayanan kota mencakup wilayah Kecamatan Koto Tangah (Lubuk buaya, Aia pacah), Bandar buat dan Bungus teluk kabung

c. Pusat lingkungan, mencakupwilayah Anak Air, Lubuk Minturun, Gunung Sarik dan Ketaping

Berdasarkan perbandingan penentuan pusat pengembangan wilayah kota antara hasil analisis dan kebijakan dalam rencana tata ruang wilayah, maka didapatkan hasil penelitian ini adalah bahwa untuk Kecamatan Koto Tangah dilihat dari aspek jarak dan fasilitas, serta jumlah penduduk Kecamatan Koto Tangah termasuk kedalam kategori 
Kecamatan yang sesuai dijadikan perentukan pengembangan wilayah Kota, dan dilihat dari kebijakan rencana tata ruang wilayah (RTRW), bahwa di kecamatan Koto Tangah ini akan dikembangakan beberapa perencanaan pengembangan wilayah kota berupa; kawasan perdagangan dan jasa, kawasan pendidikan, kawasan pemerintahan kota, serta kawasan permukiman. Oleh karena itu Kecamatan Koto Tangah merupakan sub pusat kota di Kota Padang.

\section{KESIMPULAN}

Hasil penelitian ini menemukan bahwa, kelurahan Aia Pacah kurang sesuai dijadikan sebagai pusat pengembangan wilayah kota, karena dilihat daya tarik antar lokasi Kelurahan, kelurahan Aia Pacah tergolong kelurahan yang masih kurang daya tarik masyarakat untuk melakukan aktivitas di kelurahan tersebut. Sedangkan pada kelurahan Lubuk Buaya sesuai dijadikan sebagai pusat pengembangan wilayah kota karena pada kelurahan tersebut dari segi fasilitas dan interaksi antar lokasi Kelurahan di Kecamatan Koto Tangah tinggi masyarakat untuk melakukan aktivitas di kelurahan tersebut. Untuk pengembangan wilayah kota pada masing-masing Kecamatan di Kota Padang, maka terdapat kecamatan yang sesuai dijadikan pusat pengembangan wilayah Kota yaitu terdapat pada Kecamatan Koto Tangah dan Kecamatan Padang Timur, karena dari segi fasilitas dan daya tarik masyarakat pada kedua kecamatan tersebut sangat mendukung dan memadai dijadikansebagai pusat pengembangan wilayah kota di Kota Padang.

\section{DAFTAR PUSTAKA}

BAPPEDA. 2010 Tentang Perencanaan Pengembangan Wilayah.

BAPPEDA. 2012 Tentang Kawasan Strategis dan Pusat Pelayanan Kota.

Dedi NS. Setiono. 2011. Ekonomi Pengembangan Wilayah. Jakarta: Penerbit Fakultas Ekonomi.

Tarigan, Robinson. 2005. Ekonomi regional, teori dan aplikasi. Jakarta: Penerbit Bumi Aksara.

Rencana Tata Ruang Wilayah Kota Padang 2010-2030

Peraturan Pemerintah Nomor 26 Tahun 2011 Tentang Penataan Ruang 